\title{
Cabinet size and governance in Sub-Saharan Africa
}

\section{Joachim Wehner $^{1}$ (1) | Linnea Mills ${ }^{2}$}

\author{
${ }^{1}$ Department of Government and School \\ of Public Policy, London School of \\ Economics and Political Science, \\ London, UK \\ ${ }^{2}$ Independent researcher

\section{Correspondence} \\ Joachim Wehner, Department of \\ Government, London School of \\ Economics and Political Science, \\ Houghton Street, London WC2A 2AE, UK \\ Email: j.h.wehner@lse.ac.uk

\section{Funding information} \\ World Bank Group
}

\begin{abstract}
There is frequent public and media concern over the cost of bloated cabinets in many Sub-Saharan African countries. Scholarship on elite clientelism links cabinet positions with corruption and practices that undermine sound policymaking. This article presents new data on the number of ministers in African governments and documents a robust negative association with several measures of governance, both across countries and in a regression framework that exploits within-country variation over time and accounts for various potential confounders. This suggests policymakers, donors, investors, and citizens should pay close attention to the number of ministers appointed to the cabinet. Although the article cautions against simplistic policy prescriptions, a sizable increase in the number of ministers is likely bad news for governance.
\end{abstract}

The number of ministers appointed to the cabinet is a frequent concern in many developing countries, especially in Sub-Saharan Africa. In 2017, Ghana's President, Nana Akufo-Addo, appointed the largest cabinet in a quarter of a century, prompting the opposition to condemn his "elephant size" government (Reuters, 2017). Conversely, when in May 2019 South Africa's President Cyril Ramaphosa cut the number of cabinet ministers from 36 to 28, many observers interpreted this as an attempt to tackle government corruption (Reuters, 2019). Beyond these anecdotes, is there a systematic relationship between the number of ministers in the cabinet, or 
cabinet size, and governance outcomes? We focus on Sub-Saharan Africa, where public and media concerns about an excessive number of ministers are common, and where prior scholarship links cabinet appointments with corruption and poor governance.

Some existing studies examine cabinet size as a determinant of government performance. One focus has been on the "common pool resource" problem in budgeting, which implies that more ministers lead to higher spending and larger deficits. Empirical work covers mostly industrialized democracies (Perotti \& Kontopoulos, 2002; Volkerink \& de Haan, 2001) and some emerging market economies and developing countries (Wehner, 2010; Woo, 2003). A more recent study by LeVan and Assenov (2016) looks at Sub-Saharan African countries, concluding that more ministries may increase expenditure but not deficits. With some exceptions discussed in the following section, other theoretical perspectives and potential consequences of cabinet size are far less frequently considered.

This article advances the study of how executive structures shape development and governance. First, we broaden the examination of the consequences of cabinet size beyond public finances, drawing on a different literature that links clientelism and cabinet appointments. Based on this perspective, we present systematic empirical evidence confirming that public concern over the governance implications of oversized cabinets is justified. In addition, our study provides a consistent and openly available update of an important data set that tracks the evolution of cabinets in Sub-Saharan Africa from 1971 to 2001 (Arriola, 2009), thus enabling further research.

We commence by setting out how cabinet size may affect governance, drawing on the literature concerned with elite clientelism and related work on African politics. We then present new data on cabinet size in Sub-Saharan African countries, extending prior work by Arriola (2009), and assess their association with a series of governance measures related to corruption and the quality of public policy. Analyzing cross-national patterns as well as within-country variation over time, we find a robust correlation between cabinet size and several measures of governance in this sample. The conclusion summarizes policy implications and explores possible avenues for further research.

\section{1 | FROM CABINETS TO GOVERNANCE}

Scholars of African politics have highlighted a link between clientelism and cabinet appointments. Van de Walle (2012) distinguishes mass clientelism and elite clientelism. Mass clientelism relies on using state resources, or patronage, to provide jobs and services for mass clienteles, typically involving party structures and electoral politics. This type of clientelism requires considerable resources and is therefore likely to take place in richer countries, also Western democracies. For poorer countries, on the other hand, clientelism is more likely to be limited to a narrower clientele, so-called elite clientelism. In Sub-Saharan Africa, the dominant form of elite clientelism is prebendalism, or "the strategic political allocation of public offices to key elites" (van de Walle, 2012, p. 113). ${ }^{1}$ In such settings, a cabinet position forms the top echelon of elite offices and can be seen as the ultimate gift, "bringing with it patronage opportunities as well as significant perks and status-enhancing privileges" (van de Walle, 2001, p. 103; see also Kroeger, 2018; LeVan \& Assenov, 2016).

Elite clientelism in the form of prebendalism is closely linked to grand corruption, which channels benefits other than the official salary to a political office holder. By promoting loyalty to the leader through the provision of rent-seeking opportunities to key political allies, such a system is permissive of corruption (Bueno de Mesquita et al., 2003). Moreover, prebendalism 
hampers "horizontal accountability" (O'Donnell, 1998) through courts, auditors, investigative agencies, or legislatures. Such institutions can be undermined by appointing allies and cronies to them who sabotage troublesome investigations (e.g., Pauw, 2017). And the handing out of cabinet positions to members of parliament based on loyalty acts as a disincentive for them to exercise effective oversight. For instance, Ghana's former President John Kufuor picked about three-quarters of his cabinet ministers from among parliamentarians, who in order to be considered had to be loyal rather than scrutinize the executive (Lindberg, 2010). ${ }^{2}$ In an earlier empirical analysis, Mills (2012) uses data for 42 African countries over the period 1985-2010 to show that cabinet size has a positive association with grand corruption. In this article, we significantly expand this analysis in terms of coverage and the measures of governance considered.

Elite clientelism can be contained by programmatic political parties, which appeal to voters on the basis of specific policies that are grounded in an ideological program (Keefer, 2013, p. 7). Programmatic parties are able to solve collective action problems and make credible commitments to deliver public goods, which requires mechanisms to discipline and sanction party leaders and members whose actions are not conducive to delivering promised policies. In contrast, clientelist politicians prefer discretion and weak oversight of the implementation of policies, so that they can extract personal benefits and channel resources to their supporters (Cruz \& Keefer, 2015). This implies that the potential for cabinet size to be associated with poor governance and corruption is especially likely in settings where programmatic political parties are weak or absent, as is the case in many Sub-Saharan African countries.

Clientelistic politics is not the only driver of cabinet size. Examining data on post-war cabinets in 17 Western European countries, Indridason and Bowler (2014) find that inter-party politics influences the size of the cabinet. As coalition parties require an agreement about the division of ministerial portfolios, increasing the size of the cabinet can at times smooth that process. Portfolios tend to be allocated roughly proportional to the governing parties' legislative strength. Achieving proportionality is difficult in small cabinets, but the problem can often be solved by adding a portfolio. Intra-party politics matters, too, when otherwise dissatisfied party members or factions are brought on board by altering the size of the cabinet. The need for coalition building through cabinet appointments is not limited to parliamentary democracies, as Cheibub (2007) shows for presidential systems in Latin America.

These arguments translate into the context of Sub-Saharan Africa, where cabinet appointments and changes can help presidents to consolidate their hold on power (Arriola, 2009; Francois et al., 2015). The co-opting of elites helps to explain why cabinets can get larger at strategically important moments, notably ahead of elections. ${ }^{3}$ Moreover, a "winner-takes-all" political system can be unstable, and governments may face frequent threats of coups. Where presidents use ministerial appointments to buy loyalty from members of the elite who might otherwise mount leadership challenges, enlarging the cabinet can increase political stability (Hyden, 2006, p. 104). A study of cabinets in 40 African countries over the period 1970-2000 confirms that cabinet appointments can extend a leader's tenure and lower the probability of being deposed through a coup, unless leaders overextend their coalitions (Arriola, 2009, p. 1350). Torgler and Frey (2012) analyze data for 100 countries over 20 years and find that large cabinets reduce the likelihood of an assassination attempt on leading officials or politicians. This helps to explain why power sharing arrangements have been used across Africa during attempts to resolve conflict. Somalia, for example, had especially large cabinets following the establishment of the Transitional Federal Government in 2004.

Overall, this discussion yields expectations about the relationship between cabinet size and governance outcomes. In Sub-Saharan Africa, bloated cabinets indicate elite clientelism, 
suggesting that additional ministers are likely to increase corruption. The latter undermines government effectiveness by diverting scarce resources from essential public services (Ablo \& Reinikka, 1998). Rent-seeking ministers also have incentives to weaken the rule of law and regulatory quality in order to be unincumbered by independent judges or transparent procedures (Pauw, 2017; Rose-Ackerman \& Palifka, 2016, p. 382-389). Yet, in analyzing these relationships, we need to account for other factors that are also associated with both cabinet size and governance outcomes, such as pressures to build coalitions or to manage conflict. Moreover, while this discussion posits that the direction of causality is from the size of the cabinet to governance, we are mindful that the opposite may be plausible, too. We return to this point following the introduction of our data set and the presentation of our empirical results.

\section{2 | A NEW DATA SET}

To take a fresh empirical look at the relationship between cabinet size and governance and policy outcomes, we assemble a range of relevant data for Sub-Saharan African countries. The variables we include fall into three main groups, which we introduce below. Appendix A provides full variable definitions and sources and summary statistics are in Table A1.

The main independent variable of interest is the number of cabinet ministers. No off-theshelf data set exists that reliably captures this information. The Cross-National Time-Series Data Archive initiated by Arthur Banks includes the size of the cabinet. ${ }^{4}$ However, the sources used are not fully disclosed and the manual warns that "[i]n many cases, counts are approximate". Instead, we build on Arriola's (2009) data set on cabinet size, as it is coded on the basis of information on the membership of cabinets obtained from a single high-quality source, Europa Publications' Africa South of the Sahara, which is published annually. Focusing on political heads who are ultimately in charge of government departments, the data set records the number of ministers with full cabinet rank for each country and year in the sample. Excluded are members of the executive without cabinet rank, notably junior or deputy ministers, and individuals with lower-level executive functions, as their authority and discretion is limited. This approach ensures the greatest possible consistency.

We updated Arriola's (2009) data set to 2014 and expanded the countries included to 48, with a total of 1,797 observations. Median cabinet size over this period is 22 and the mean is 23, but there is tremendous dispersion both within and between countries. Cabinet size in our sample ranges from 5 (the Comoros in 2002) to 53 (Cameroon in 2006). Figure 1 summarizes the data by country. ${ }^{5}$ Figure 2 shows the evolution of cabinet size in the region over the period covered by the updated data set. Cabinets were more compact at the very beginning of the period, with a mean of just 16 in 1971. Arriola (2009, p. 1347) notes an upward trend, with the mean reaching 24 by the end of the century. The new data show that the average cabinet in the region continued to expand in the new millennium, to 27 in 2014, with substantial dispersion around the mean.

We examine the relationship of cabinet size with a number of plausible outcome measures indicated by the preceding discussion. One principal source is the well-known Worldwide Governance Indicators (WGI) data set produced by the World Bank since 1996, which includes perception-based estimates across several dimensions of governance, aggregating up a number of variables from different sources (Kaufmann et al., 2010). Of these indicators, we use the variables that are closely linked to the predictions generated in the previous section. These include the measures that relate to the capacity of the government to effectively formulate and 


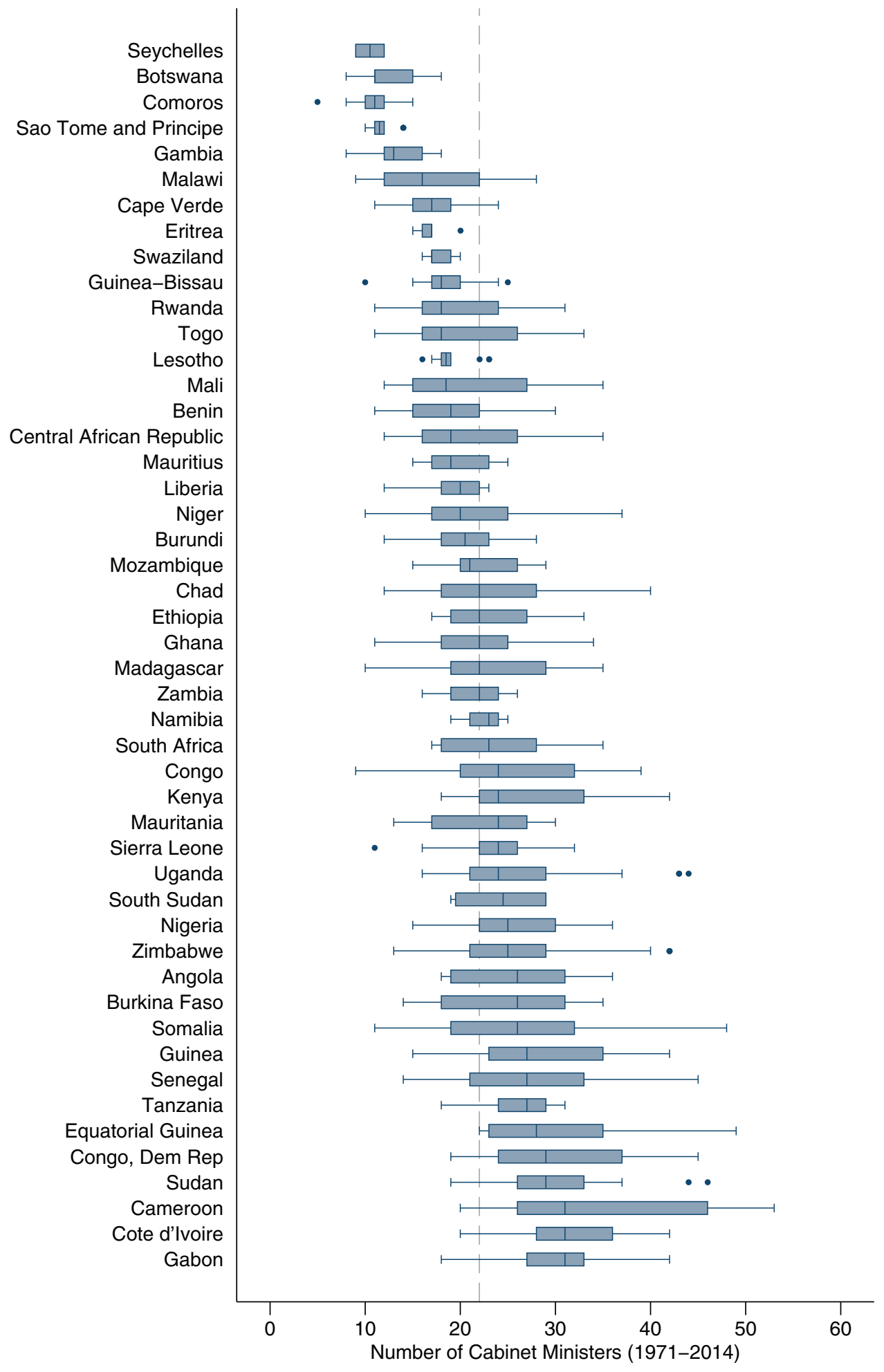

F I G U RE 1 Variation in cabinet size in Sub-Saharan Africa, 1971-2014. The dashed line indicates the pooled sample median (22). $N=1,797$. The data are from Arriola (2009) with authors' updates coded from subsequent editions of Europa Publications, Africa South of the Sahara 


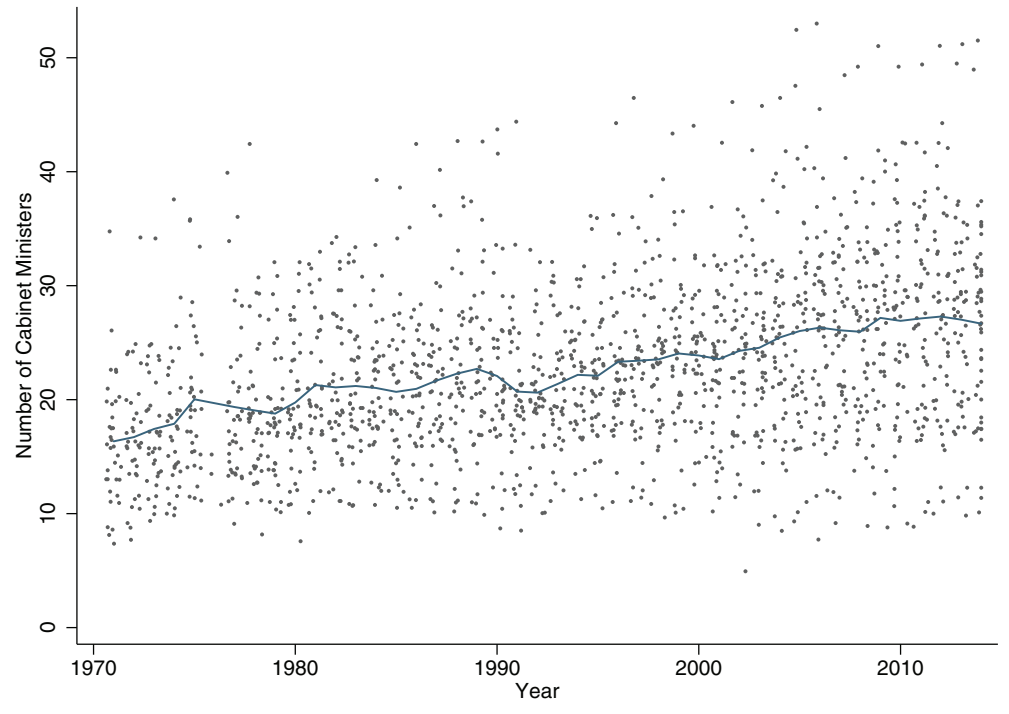

FIG URE 2 Evolution of cabinet size over time, 1971-2014. Based on the data summarized in Figure 1. The solid line indicates the annual sample mean and the dots represent annual observations. The gap in 1976 is due to missing data for most countries for this year and the mean line is smoothed over this gap

implement sound policies (Government Effectiveness, Regulatory Quality) and the respect of citizens and the state for the institutions that govern economic and social interactions among them (Rule of Law, Control of Corruption). The prior discussion of elite clientelism suggests that cabinet size should be negatively associated with all four of these measures.

There is an extensive debate around the validity and methodology of the WGI (Anheier et al., 2018; Apaza, 2009). Whether these measures capture distinct concepts is disputed, and Langbein and Knack (2010) conclude that they appear to measure the same broad concept. For robustness, we also use a novel corruption index from the Varieties of Democracy ( $V$-Dem) project that captures executive corruption and is based on expert scoring (see also Bäck et al., 2019). ${ }^{6}$ We further include the well-known Corruption Perceptions Index produced by Transparency International. It would be ideal to have objective measures of corruption, but these tend to be country specific - such as audit outcomes indicating corruption (Ferraz \& Finan, 2008) or amounts of funding diverted from authorized purposes (Olken, 2007). Hence, perception-based measures remain important, especially when examining cross-national data.

A final addition is from the Ibrahim Index of African Governance. Here, we use their measure of human development, aggregating 26 indicators of service provision and outcomes related to welfare, education, and health, which prior research shows are negatively affected by corruption (e.g., Reinikka \& Svensson, 2011). This measure complements the previous ones by focusing on the consequences for essential services that directly affect the vast majority of the population, such as primary school completion and immunization. To ensure comparability and to aid interpretation, where required, we rescale measures to a theoretical range from zero to $100 .{ }^{7}$ Despite different methodological approaches and variation in focus, most of these measures are highly correlated (see Table A2).

We draw on the World Bank/Inter-American Development Bank's Database of Political Institutions to control for a number of underlying pressures on cabinet size identified in the preceding section. We include the partisan fractionalization of the executive, as multi-party coalitions may lead to increased cabinet size to accommodate politicians from across the different parties that participate in the government. Next, we use indicators of whether the chief executive or defense minister are military officers. A strong presence of military officers may suggest 
threats to the stability of the government, which presidents might attempt to manage by enlarging the number of ministers to accommodate important allies and potential rivals. In addition, we use the coding by Cruz and Keefer (2015) to account for the presence of programmatic parties, which can limit clientelism and promote cohesive policies.

Moreover, we measure the number of years the chief executive has been in office. A long tenure may suggest that elite clientelism is particularly entrenched and highly personalized. At the time of writing, the longest-serving president in the world is Teodoro Obiang Nguema Mbasogo of Equatorial Guinea, who took office in 1979. Equatorial Guinea is also among the worst countries in the world on several governance indicators-in 2014, for instance, it had the worst score of all countries in our sample on the Control of Corruption measure. Next, to account for the possibility that corruption responds to electoral pressures, we control for the number of years before the end of the current electoral term. Further, it is possible that close links between the government and business may affect a government's approach to regulation and policy, or its susceptibility to bribes. To account for this possibility, we include an indicator of whether the head of the executive is from a party to the left of the ideological spectrum. These measures, too, are from the Database of Political Institutions.

Finally, we also account for the broader political and economic context of a country. Democracies have checks and balances that can help to limit corruption and expose the selection of leaders to electoral competition, so we control for it alternatively with variables from the Polity and $V$-Dem data sets. Moreover, as prior research finds that economic development is associated with better government performance (La Porta et al., 1999), we include GDP per capita (from the World Development Indicators data set). The full data set for this article is openly available as part of the replication archive.

\section{3 | RESULTS}

For a first look at the bivariate relationship of cabinet size with governance we average the available data for the 10 most recent years included in our data set and focus on cross-national patterns. The results are displayed in Figure 3. All measures of governance have a negative relationship with cabinet size, which in all seven panels (a to g) implies worse governance. All correlations are significant at the $1 \%$ level with coefficients ranging from -0.49 (for Control of Corruption) to -0.13 (Regulatory Quality). Yet there is a substantial amount of variation that is not accounted for by cabinet size, which is expected. These cross-national patterns are affected by a potentially large number of observable and unobservable characteristics.

To probe these relationships further, we run a set of regressions that exploit within-country variation and account for several potentially confounding variables discussed above. The basic specification is as follows:

Governance $_{i, t}=\beta_{1}$ Cabinet $_{i, t}+\beta_{k}$ Controls $_{i, t}+$ Country $_{i}+$ Year $_{t}+\varepsilon_{i, t}$

A governance indicator for country $i$ in year $t$ is regressed onto our measure of cabinet size and $k$ controls discussed in the previous section. Country fixed effects absorb unchanging country characteristics and much of the explanatory power of slowly or rarely changing variables, such as a country's size or natural geographic features, the ethnic heterogeneity of its population, or whether it has a presidential or parliamentary system of government. Year effects account for common shocks that may have region-wide governance implications. In particular, the collapse of the Soviet Union altered the politics of foreign aid and increased the effectiveness of Western development assistance in promoting governance reforms across the region 

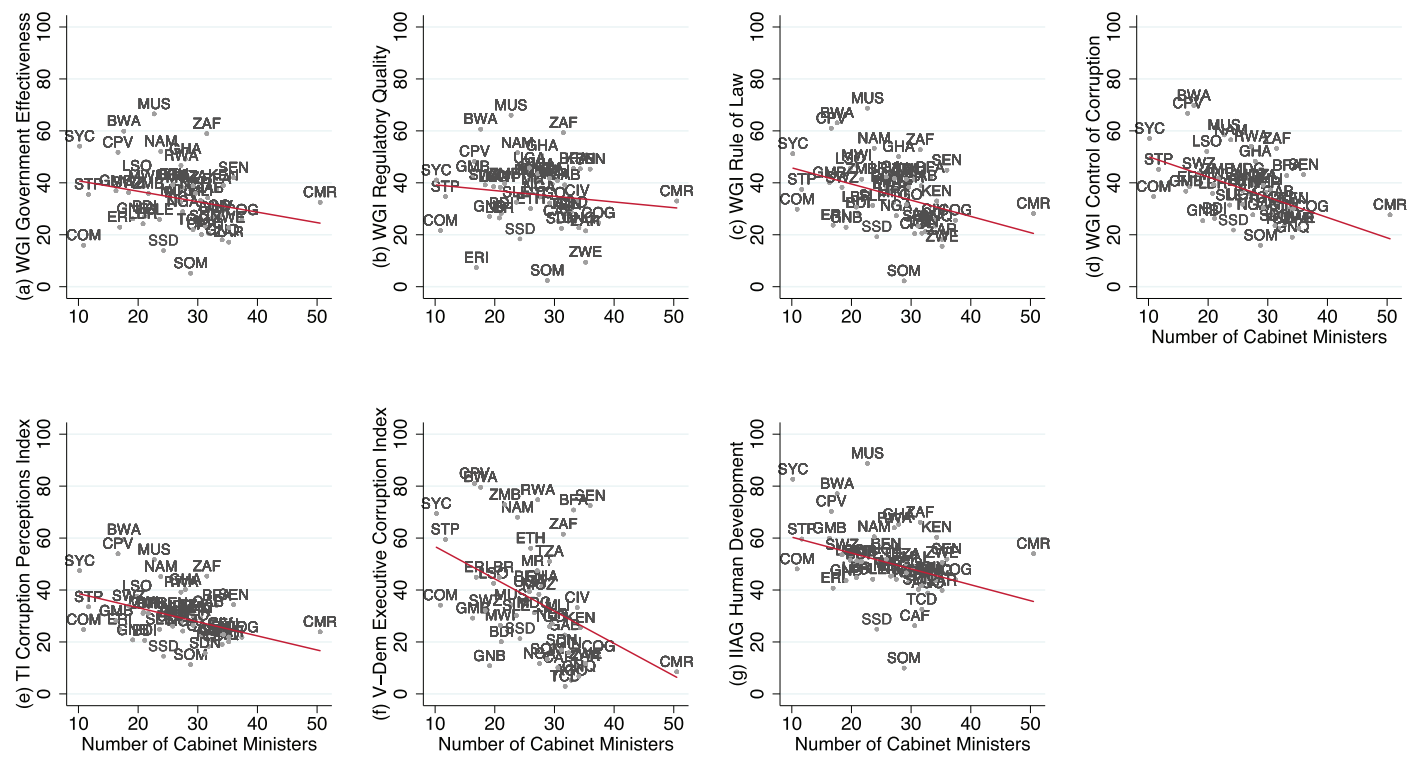

F I G U RE 3 Cabinet size has a negative correlation with governance indicators, 2005-2014 averages. The variables on the $Y$-axes are from the September 2018 update of the Worldwide Governance Indicators (WGI; panels a-d), various editions of the Corruption Perceptions Index produced by Transparency International (TI; panel e), the July 2018 version of the V-Dem data set (panel f), and the 2018 Ibrahim Index of African Governance (IIAG; panel g). See Appendix A for full variable definitions and sources. Country codes are taken from the IMF's International Financial Statistics and included in Table A3. The available data are averaged over the 2005-2014 period

(Dunning, 2004). Subsequently, the emergence of China as a major aid actor sparked debates about the implications this may have for development and governance in Africa (Brautigam, 2009; Woods, 2008). Our inclusion of country and year fixed effects thus helps to contain bias by accounting for a range of potential confounders in these two categories.

Table 1 displays the results. As in the cross-country averages, cabinet size has a consistently negative association with measures of governance in these regressions. The coefficients on this variable are significant in five of seven cases, except for Regulatory Quality and the Executive Corruption Index, where they get close to statistical significance at conventional levels. Substantively, the size of the coefficients appears modest: Adding 10 ministers to the cabinet is associated with reductions of up to 2.3 percentage points across these measures of governance. Yet given that many countries in the region have low scores on these indicators, the estimated consequences of plausible changes to cabinet size would not be negligible. For instance, our results imply that Angola's Corruption Perceptions Index score in 2014 would have been more than $15 \%$ higher, at 22 rather than 19, if instead of 36 ministers its cabinet had been half that size, as in nearby Botswana. ${ }^{8}$ Looking at the control variables, two patterns stand out: rich countries do better on these measures and left leaders tend to do worse.

Although the time series available for most measures of governance is short, which gives rise to Nickell bias in dynamic models with fixed effects, we checked whether our results are robust to including a lagged dependent variable. We exclude the data from the Ibrahim Index, which only start in 2008. These supplementary results are reported in Table 2 . In terms of our variable of interest, the basic pattern of results goes through. While the coefficients on the cabinet size variable are smaller, the estimates still achieve statistical significance at conventional 
TABLE 1 Main regression results

\begin{tabular}{|c|c|c|c|c|c|c|c|}
\hline & $\begin{array}{l}\text { (1) } \\
\text { GE }\end{array}$ & $\begin{array}{l}\text { (2) } \\
\text { RQ }\end{array}$ & $\begin{array}{l}\text { (3) } \\
\text { RL }\end{array}$ & $\begin{array}{l}(4) \\
\mathrm{CC}\end{array}$ & $\begin{array}{l}\text { (5) } \\
\text { CPI }\end{array}$ & $\begin{array}{l}\text { (6) } \\
\text { ECI }\end{array}$ & $\begin{array}{l}\text { (7) } \\
\text { IIAG }\end{array}$ \\
\hline \multirow[t]{2}{*}{ Cabinet size } & $-0.143^{* * *}$ & -0.103 & $-0.167^{* * *}$ & $-0.153^{* * *}$ & $-0.158^{* *}$ & -0.228 & $-0.063^{* *}$ \\
\hline & $(0.051)$ & $(0.063)$ & $(0.053)$ & $(0.053)$ & $(0.072)$ & $(0.179)$ & $(0.030)$ \\
\hline \multirow[t]{2}{*}{ Polity } & 0.137 & 0.244 & $0.416^{* *}$ & 0.039 & -0.163 & & 0.004 \\
\hline & $(0.200)$ & $(0.176)$ & $(0.164)$ & $(0.140)$ & $(0.183)$ & & $(0.112)$ \\
\hline \multirow[t]{2}{*}{ Electoral democracy } & & & & & & 13.353 & \\
\hline & & & & & & (11.674) & \\
\hline \multirow[t]{2}{*}{ Left } & $-3.044^{* *}$ & -0.861 & $-2.441^{*}$ & $-3.256^{* *}$ & $-1.979^{*}$ & -1.601 & 0.222 \\
\hline & $(1.249)$ & $(1.355)$ & (1.403) & $(1.227)$ & $(1.022)$ & $(1.950)$ & $(1.081)$ \\
\hline \multirow{2}{*}{$\begin{array}{l}\text { Government } \\
\text { fractionalization }\end{array}$} & -2.751 & -1.724 & -0.703 & -1.500 & -1.165 & 3.603 & -0.209 \\
\hline & $(2.553)$ & $(1.973)$ & $(1.746)$ & $(1.772)$ & (1.688) & $(4.748)$ & $(1.718)$ \\
\hline \multirow{2}{*}{$\begin{array}{l}\text { Programmatic } \\
\text { parties }\end{array}$} & 1.393 & 0.976 & 1.265 & 0.639 & -0.725 & 0.883 & -3.092 \\
\hline & $(1.546)$ & (1.199) & $(1.231)$ & $(1.368)$ & $(2.002)$ & $(4.086)$ & $(2.224)$ \\
\hline \multirow[t]{2}{*}{ GDP per capita } & $8.476^{*}$ & $12.307^{* * *}$ & $8.101^{* *}$ & $6.881^{* *}$ & $12.186^{* * *}$ & 6.882 & 5.808 \\
\hline & $(4.258)$ & $(3.750)$ & $(3.537)$ & $(2.744)$ & $(2.414)$ & $(5.385)$ & $(3.781)$ \\
\hline \multirow[t]{2}{*}{ Military } & 0.574 & 0.342 & -0.202 & 0.484 & $-4.378^{* * *}$ & -1.899 & -0.183 \\
\hline & (1.218) & $(1.146)$ & (1.069) & $(0.735)$ & $(0.962)$ & $(3.729)$ & $(0.839)$ \\
\hline \multirow[t]{2}{*}{ Defense minister } & -0.099 & 0.633 & 1.559 & 0.503 & $-2.189^{*}$ & 1.306 & -0.239 \\
\hline & $(1.265)$ & $(1.254)$ & $(1.151)$ & $(0.579)$ & $(1.129)$ & $(1.907)$ & $(0.725)$ \\
\hline \multirow[t]{2}{*}{ Years in office } & 0.088 & $0.137^{* *}$ & 0.075 & -0.069 & 0.030 & -0.200 & -0.001 \\
\hline & (0.067) & $(0.065)$ & $(0.057)$ & $(0.057)$ & $(0.057)$ & $(0.129)$ & $(0.048)$ \\
\hline \multirow[t]{2}{*}{ Years to election } & 0.095 & 0.096 & 0.050 & 0.061 & 0.053 & -0.025 & 0.021 \\
\hline & $(0.071)$ & $(0.085)$ & $(0.086)$ & $(0.086)$ & $(0.119)$ & $(0.177)$ & $(0.081)$ \\
\hline Country FEs & Yes & Yes & Yes & Yes & Yes & Yes & Yes \\
\hline Year FEs & Yes & Yes & Yes & Yes & Yes & Yes & Yes \\
\hline Observations & 560 & 561 & 561 & 561 & 479 & 1,017 & 262 \\
\hline$R$-squared (within) & 0.213 & 0.237 & 0.212 & 0.152 & 0.457 & 0.151 & 0.512 \\
\hline Countries & 40 & 40 & 40 & 40 & 40 & 40 & 40 \\
\hline
\end{tabular}

Note: Standard errors clustered by country in parentheses. Dependent variables are from the September 2018 update of the Worldwide Governance Indicators (estimates of GE, Government Effectiveness; RQ, Regulatory Quality; RL, Rule of Law; CC, Control of Corruption), various editions of the Corruption Perceptions Index (CPI), the July 2018 version of the V-Dem data set (ECI, Executive Corruption Index, reversed), and the 2018 Ibrahim Index of African Governance (IIAG). See Appendix A for full variable definitions and sources.

${ }^{*} p<0.1$.

*** $p<0.05$.

${ }^{* * *} p<0.01$.

levels in three of six regressions. Executive corruption as measured with the $V$-Dem data is largely accounted for by the lagged dependent variable. In terms of control variables, one notable change is that the coefficients on the democracy measures are more precisely estimated. Democracy has a positive and statistically significant association with three of six governance measures. 
T A B L E 2 Supplementary regressions with lagged dependent variable

\begin{tabular}{|c|c|c|c|c|c|c|}
\hline & & & & & & \\
\hline & GE & RQ & RL & CC & CPI & ECI \\
\hline \multirow[t]{2}{*}{ Cabinet size } & $-0.076^{* *}$ & -0.035 & $-0.090^{* * *}$ & $-0.097^{* * *}$ & -0.061 & 0.005 \\
\hline & $(0.031)$ & $(0.025)$ & $(0.026)$ & $(0.032)$ & $(0.042)$ & $(0.034)$ \\
\hline \multirow[t]{2}{*}{ Polity } & $0.225^{* *}$ & $0.219^{* * *}$ & $0.305^{* *}$ & 0.161 & -0.093 & \\
\hline & $(0.096)$ & $(0.076)$ & $(0.136)$ & $(0.111)$ & $(0.087)$ & \\
\hline \multirow[t]{2}{*}{ Electoral democracy } & & & & & & 3.937 \\
\hline & & & & & & $(3.302)$ \\
\hline \multirow[t]{2}{*}{ Left } & $-1.696^{* * *}$ & -0.156 & $-1.146^{* *}$ & $-1.455^{* *}$ & -0.274 & -0.843 \\
\hline & $(0.497)$ & $(0.554)$ & $(0.459)$ & $(0.642)$ & $(0.497)$ & $(0.553)$ \\
\hline \multirow[t]{2}{*}{ Government fractionalization } & $-2.177^{*}$ & 0.460 & -1.148 & -0.322 & -0.864 & -0.357 \\
\hline & $(1.196)$ & $(0.974)$ & (1.163) & $(1.156)$ & $(1.162)$ & $(0.960)$ \\
\hline \multirow[t]{2}{*}{ Programmatic parties } & -0.047 & -0.482 & 0.305 & -0.765 & -0.362 & 0.593 \\
\hline & $(0.617)$ & $(0.776)$ & $(0.740)$ & $(0.907)$ & $(0.963)$ & $(0.870)$ \\
\hline \multirow[t]{2}{*}{ GDP per capita } & $3.816^{* *}$ & $2.934^{*}$ & $3.545^{* *}$ & $2.873^{*}$ & $4.191^{* *}$ & -1.127 \\
\hline & (1.884) & (1.517) & (1.602) & (1.578) & (1.927) & $(0.762)$ \\
\hline \multirow[t]{2}{*}{ Military } & -0.497 & 0.834 & 1.016 & 0.558 & $-1.737^{* *}$ & $1.978^{* *}$ \\
\hline & $(0.620)$ & $(0.518)$ & $(1.221)$ & $(0.383)$ & $(0.693)$ & $(0.842)$ \\
\hline \multirow[t]{2}{*}{ Defense minister } & -0.270 & -0.470 & $1.246^{* *}$ & 0.430 & $-1.083^{*}$ & 0.014 \\
\hline & $(0.506)$ & $(0.357)$ & $(0.562)$ & $(0.589)$ & $(0.642)$ & $(0.491)$ \\
\hline \multirow[t]{2}{*}{ Years in office } & $0.055^{* *}$ & $0.053^{* * *}$ & 0.010 & -0.035 & $-0.042^{*}$ & -0.015 \\
\hline & $(0.026)$ & $(0.017)$ & $(0.023)$ & $(0.024)$ & $(0.023)$ & $(0.018)$ \\
\hline \multirow[t]{2}{*}{ Years to election } & 0.037 & -0.023 & -0.036 & -0.019 & 0.063 & -0.002 \\
\hline & $(0.050)$ & $(0.058)$ & $(0.054)$ & $(0.070)$ & $(0.084)$ & $(0.066)$ \\
\hline \multirow[t]{2}{*}{ Lagged dependent variable } & $0.520^{* * *}$ & $0.656^{* * *}$ & $0.622^{* * *}$ & $0.634^{* * *}$ & $0.598^{* * *}$ & $0.935^{* * *}$ \\
\hline & $(0.046)$ & $(0.046)$ & $(0.050)$ & $(0.079)$ & $(0.051)$ & $(0.020)$ \\
\hline Country FEs & Yes & Yes & Yes & Yes & Yes & Yes \\
\hline Year FEs & Yes & Yes & Yes & Yes & Yes & Yes \\
\hline Observations & 436 & 436 & 436 & 436 & 440 & 1,001 \\
\hline$R$-squared (within) & 0.483 & 0.580 & 0.577 & 0.552 & 0.698 & 0.848 \\
\hline Countries & 40 & 40 & 40 & 40 & 40 & 40 \\
\hline
\end{tabular}

Note: Standard errors clustered by country in parentheses. Dependent variables are from the September 2018 update of the Worldwide Governance Indicators (estimates of GE, Government Effectiveness; RQ, Regulatory Quality; RL, Rule of Law; CC, Control of Corruption), various editions of the Corruption Perceptions Index (CPI), and the July 2018 version of the V-Dem data set (ECI, Executive Corruption Index, reversed). See Appendix A for full variable definitions and sources.

${ }^{*} p<0.1$.

*** $p<0.05$.

${ }^{* * *} p<0.01$.

We also considered further specifications that are included in our replication files (Wehner \& Mills, 2021). It is possible that an increase in cabinet size takes time to translate into a deterioration in governance, for example if politicians once appointed need time to 
manipulate regulations or to extract bribes. When we lag the number of ministers, the overall pattern of results is very similar. Compared with the main results in Table 1, the magnitude of the coefficients of interest decreases in three regressions and increases in four, and six of them now achieve statistical significance at conventional levels.

Recall that our discussion of programmatic parties highlighted their interest to contain elite clientelism to ensure the delivery of promised policies (Keefer, 2013). Hence, the presence of programmatic parties might dampen, even eliminate, the negative effect of cabinet size on governance. A related argument, assuming disciplined political parties, has been made in the literature on cabinet size and fiscal policy, which in a different sample finds that the positive effect of the number of ministers on spending and deficits is increasing in partisan fragmentation (Wehner, 2010, p. 646). We augment our basic model with an interaction between cabinet size and our measure of programmatic parties (Kam \& Franzese, 2007). The coefficient on the interaction term has an unexpected negative sign in five out of the seven regressions, but it never reaches conventional thresholds of statistical significance. Whether another measure of programmatic parties, or a different context, would yield stronger evidence for a conditional effect deserves attention in follow-up work.

In addition, we considered whether the effect of cabinet size on governance may depend on the system of government. This could matter for the type of politician who becomes a minister and for the degree to which the chief executive can sanction individual cabinet members for corruption or poor performance. Presidents potentially have a much wider ministerial talent pool then prime ministers in parliamentary systems, who depend on the confidence of their parliament and-either de jure or de facto-are likely to select ministers more narrowly from among its members. Although a number of African countries had parliamentary forms of government at independence, many soon switched so this group is now small and consists of Botswana, Ethiopia, Lesotho, Mauritius, and South Africa (Robinson \& Torvik, 2016). A far larger number has a presidential or some form of semi-presidential system. As a result, any regressions in this sample are highly sensitive to small variations in the countries classified as parliamentary. Moreover, this distinction is correlated with many other time-invariant or slowly changing country characteristics, such as legal origin and colonial heritage.

With this limitation in mind, we nonetheless checked whether the relationship between cabinet size and governance in this sample is conditional on whether a country has parliamentary form of government. When we augment our main model with an interaction between cabinet size and an indicator of the five parliamentary systems noted above, the coefficient on the interaction term is negative in three regressions and statistically significant in two of these. The coefficient on the interaction term is positive, although statistically insignificant albeit borderline in one instance, in the remaining four regressions. We hesitate to draw conclusions from such a mixed pattern of results, and the data limitations discussed above do not allow us take this analysis further in meaningful ways. Therefore, we recommend this line of inquiry for another context that offers greater variation in the form of government.

One final caveat: While our estimates document robust correlation, our data do not allow us to clarify the direction of these relationships. Does an increase in the size of the cabinet lead to worse governance? Or do venal rulers appoint large cabinets? In other words, while our setup assumes that the direction of causality is from the size of the cabinet to governance, the opposite is plausible, too. This uncertainty about reciprocal causality needs to be tackled in follow-up work with empirical settings that allow the identification of causal effects. 


\section{4 | CONCLUSIONS AND IMPLICATIONS}

The overall takeaway from our analysis is that cabinet size has a negative association with a basket of widely used measures of governance, both when looking at cross-country averages and when we exploit within-country variation. This pattern is robust to a demanding regression framework that accounts for time-invariant country characteristics and common shocks, as well as several variables the literature identifies as linked to the number of ministers, and which may also affect governance outcomes. We acknowledge that further research needs to investigate reciprocal causation and clarify the extent to which large cabinets lead to corruption, or vice versa. Although we make no causal claims, the systematic and robust correlations we document have significant policy relevance.

One crucial implication is that a large increase in cabinet size should alert policymakers, donors, investors, and citizens of the potential impact on governance. In Kenya, for example, presidents have used cabinet appointments as instruments of patronage, resulting in cabinets of more than 30 ministers as well as similar numbers of assistant ministers. The inflation in cabinet positions must have been perceived as having been associated with bad outcomes, since a restriction to 22 cabinet secretaries was drafted into the new constitution of 2010 (Kramon \& Posner, 2011). Indeed, assuming that there is a fixed amount of resources to monitor individual politicians, a more compact number of ministers may allow for more concentrated oversight and could strengthen accountability. Interpreting increases in the size of the cabinet as an early warning signal of potential governance deteriorations could help to mobilize and speed up the response from actors who may be able to counter this threat.

At the same time, where the political reward system is based on extra-legal perks, formalistic approaches may not yield intended consequences, unless they also tackle these underlying dynamics. This is one reason why anti-corruption commissions across Africa and elsewhere have a mixed track record in fighting corruption (Doig et al., 2005; Rose-Ackerman \& Palifka, 2016, p. 391-395). Moreover, allowance might have to be made for the political management functions of cabinet appointments, which can contribute to overall stability and help contain political tensions-even if this entails a price in terms of other dimensions of governance. Such trade-offs should be kept in mind when investigating specific cases more closely and when formulating policy recommendations for a particular setting.

We acknowledge that other aspects of cabinet appointments may have governance consequences, too, notably the personal characteristics of individuals selected for ministerial office (Besley, 2005; Hallerberg \& Wehner, 2020). This is illustrated by South African President Jakob Zuma's deliberate appointment of incompetent and obedient ministers so as to facilitate corruption, for instance in December 2015 when he replaced his respected finance minister with an obscure backbencher, precipitating a crash in the country's currency (Pauw, 2017, p. 20-21). Moreover, the stability of cabinets is also important. Martínez-Gallardo (2010) notes that frequent ministerial turnover has a negative effect on the ability of ministers to credibly commit to long-term policy, with negative implications for policy stability and the quality of governance more broadly. There may be a link between the personal characteristics of ministers, their turnover, and the size of cabinets, which deserves further analysis.

To what extent are the results relevant beyond Sub-Saharan Africa? The underlying arguments linking cabinet size to poor governance in this context focus on the role of elite clientelism. It is plausible that a similar pattern exists in other regions where this form of clientelism is dominant. Yet settings where clientelistic relationships are weaker and programmatic parties stronger may also suffer governance problems from overly large cabinets, although perhaps for different reasons. For instance, an inquiry by a U.K. parliamentary 
committee detected "a growing consensus that the ever increasing number of ministers harms the effectiveness of government" (House of Commons, 2010, p. 7) and described a range of pathologies that can arise in governments with too many ministers. These include coordination challenges and the proliferation of initiatives that serve to raise the public profile of individual ministers but disrupt the smooth running of government. While, ultimately, questions of external validity must be answered with further research, this suggests that large cabinets are likely to be problematic more generally.

\section{ACKNOWLEDGMENTS}

We are grateful for comments from Peter Ladegaard, Philip Keefer, Aart C. Kraay, and two anonymous reviewers. Funding for this research was provided by the Equitable Growth, Finance and Institutions Vice Presidency of the World Bank. All findings, interpretations, and conclusions are entirely those of the authors.

\section{CONFLICT OF INTEREST}

No conflict of interest has been declared by the authors.

\section{ENDNOTES}

${ }^{1}$ In the words of van de Walle (2012, p. 114): "Hiring a member of one's ethnic group to a senior position in the customs office is an example of patronage. Allowing the customs officer to use the position for personal enrichment by manipulating import and export taxes is an example of a prebend."

${ }^{2}$ This approach is not limited to African countries. In the United Kingdom, there has been a significant increase in junior ministers without cabinet rank over the past decades. This has boosted the "payroll vote," comprising Members of Parliament with a government job who are expected to vote as instructed or resign (House of Commons, 2010, p. 8).

${ }^{3}$ In addition, cabinet reshuffles can be used to create an atmosphere of "perpetual musical chairs" that prevents individual ministers from amassing too much power (Roessler, 2011, p. 309).

${ }^{4}$ Cabinet size is captured by the Polit 10 variable in the 2018 edition of the Banks data set.

${ }^{5}$ The correlation of our data with the Banks data is 0.73 . In 55 cases, the ministerial count by Banks differs by more than 10 from ours.

${ }^{6}$ We also used a second index that captures wider public sector corruption and obtained very similar results. In our sample, the correlation between the $V$-Dem executive and public sector corruption indices is 0.82 .

${ }^{7}$ The units of the WGI are those of a standard normal random variable, with zero mean, unit standard deviation, and ranging approximately from -2.5 to 2.5 (Kaufmann et al., 2010, p. 9). Some extreme scores are outside this range. In our sample, five scores are slightly below zero on our rescaled Regulatory Quality and Rule of Law indicators (see Table A1). All five of these are for Somalia and fall between 2006 and 2009, a period of civil war.

${ }^{8}$ The estimates with this measure differ from those in an earlier working paper version (Wehner \& Mills, 2020) due to a small number of corrections to source data.

\section{DATA AVAILABILITY STATEMENT}

The data and replication code that support the findings of this study are openly available on the Harvard Dataverse at https://doi.org/10.7910/DVN/Q9NGJW.

\section{ORCID}




\section{REFERENCES}

Ablo, E., \& Reinikka, R. (1998). Do budgets really matter? Evidence from public spending on education and health in Uganda. In World Bank policy research working paper 1926. Washington, DC: World Bank.

Anheier, H. K., Haber, M., \& Kayser, M. (Eds.). (2018). Governance indicators: Approaches, progress, promise. Oxford University Press: Oxford.

Apaza, C. (2009). Measuring governance and corruption through the worldwide governance indicators: Critiques, responses, and ongoing scholarly discussion. PS: Political Science and Politics, 42(1), 139-143.

Arriola, L. R. (2009). Patronage and political stability in Africa. Comparative Political Studies, 42(10), 1339-1362.

Bäck, H., Teorell, J., \& Lindberg, S. I. (2019). Cabinets, prime ministers, and corruption: A comparative analysis of parliamentary governments in post-war Europe. Political Studies, 67(1), 149-170.

Besley, T. (2005). Political selection. Journal of Economic Perspectives, 19(3), 43-60.

Brautigam, D. (2009). The Dragon's gift: The real story of China in Africa. Oxford: Oxford University Press.

Bueno de Mesquita, B., Smith, A., Siverson, R. M., \& Morrow, J. D. (2003). The logic of political survival. Cambridge, MA: MIT Press.

Cheibub, J. A. (2007). Presidentialism, parliamentarism, and democracy. New York, NY: Cambridge University Press.

Cruz, C., \& Keefer, P. (2015). Political parties, Clientelism, and bureaucratic reform. Comparative Political Studies, 48(14), 1942-1973.

Doig, A., Watt, D., \& Williams, R. (2005). Measuring 'success' in five African anti-corruption commissions: The cases of Ghana, Malawi, Tanzania, Uganda and Zambia. U4 Report. Bergen: Chr. Michelsen Institute.

Dunning, T. (2004). Conditioning the effects of aid: Cold war politics, donor credibility, and democracy in Africa. International Organization, 58(2), 409-423.

Ferraz, C., \& Finan, F. (2008). Exposing corrupt politicians: The effects of Brazil's publicly released audits on electoral outcomes. Quarterly Journal of Economics, 123(2), 703-745.

Francois, P., Rainer, I., \& Trebbi, F. (2015). How is power shared in Africa? Econometrica, 83(2), 465-503.

Hallerberg, M., \& Wehner, J. (2020). When do you get economists as policy makers? British Journal of Political Science, 50(3), 1193-1205.

House of Commons [UK]. (2010). Too many ministers? Public administration select committee, ninth report of session 2009-10. HC 457, 16 March. London: The Stationery Office.

Hyden, G. (2006). African politics in comparative perspective. New York, NY: Cambridge University Press.

Indridason, I. H., \& Bowler, S. (2014). Determinants of cabinet size. European Journal of Political Research, 53(2), 381-403.

Kam, C. D., \& Franzese, R. J. (2007). Modeling and interpreting interactive hypotheses in regression analysis. Ann Arbor, MI: University of Michigan Press.

Kaufmann, D., Kraay, A., \& Mastruzzi, M. (2010). The worldwide governance indicators: Methodology and analytical issues. In World Bank Policy Research Working Paper 5430. World Bank: Washington, DC.

Keefer, P. (2013). Organizing for prosperity: Collective action, political parties and the political economy of development. In World Bank Policy Research Working Paper 6583. World Bank: Washington, DC.

Kramon, E., \& Posner, D. N. (2011). Kenya's new constitution. Journal of Democracy, 22(2), 89-103.

Kroeger, A. M. (2018). Dominant party rule, elections, and cabinet instability in African autocracies. British Journal of Political Science (Forthcoming, 50, 79-101. https://doi.org/10.1017/S0007123417000497

La Porta, R., Lopez-de-Silanes, F., Shleifer, A., \& Vishny, R. (1999). The quality of government. Journal of Law, Economics, and Organization, 15(1), 222-279.

Langbein, L., \& Knack, S. (2010). The worldwide governance indicators: Six, one, or none? Journal of Development Studies, 46(2), 350-370.

LeVan, A. C., \& Assenov, A. (2016). Parties or portfolio? The economic consequences of Africa's big cabinets. Government and Opposition, 51(4), 661-690.

Lindberg, S. (2010). What accountability pressures do MPs in Africa face and how do they respond? Evidence from Ghana. Journal of Modern African Studies, 48(1), 117-142.

Martínez-Gallardo, C. (2010). Inside the cabinet: The influence of ministers in the policymaking process. In C. Scartascini, E. Stein, \& M. Tommasi (Eds.), How democracy works: Political institutions, actors, and arenas in Latin American policymaking (pp. 119-145). Washington, DC: Inter-American Development Bank. 
Mills, L. (2012). Questionable assumptions and unintended consequences: A critical assessment of the international donor Community's fight against corruption in sub-Saharan Africa ( $\mathrm{PhD}$ thesis). London School of Economics and Political Science, London. http://etheses.lse.ac.uk/467/.

O'Donnell, G. (1998). Horizontal accountability in new democracies. Journal of Democracy, 9(3), 112-126.

Olken, B. A. (2007). Monitoring corruption: Evidence from a field experiment in Indonesia. Journal of Political Economy, 115(2), 200-249.

Pauw, J. (2017). The President's keepers: Those keeping Zuma in power and out of prison. Cape Town: Tafelberg.

Perotti, R., \& Kontopoulos, Y. (2002). Fragmented fiscal policy. Journal of Public Economics, 86(2), 191-222.

Reinikka, R., \& Svensson, J. (2011). The power of information in public services: Evidence from education in Uganda. Journal of Public Economics, 95(7-8), 956-966.

Reuters (2017). Ghana opposition slams president over 'Elephant Size' government. March 16. https://www. reuters.com/article/us-ghana-politics/ghana-opposition-slams-president-over-elephant-size-governmentidUSKBN16N2TU.

Reuters (2019). South Africa's Ramaphosa retains Mboweni, Gordhan in new, leaner cabinet. May 29. https:// www.reuters.com/article/us-safrica-politics/south-africas-ramaphosa-retains-mboweni-gordhan-in-newleaner-cabinet-idUSKCN1SZ1VG.

Robinson, J. A., \& Torvik, R. (2016). Endogenous Presidentialism. Journal of the European Economic Association, 14(4), 907-942.

Roessler, P. (2011). The enemy within: Personal rule, coups, and civil war in Africa. World Politics, 63(2), 300-346.

Rose-Ackerman, S., \& Palifka, B. J. (2016). Corruption and government: Causes, consequences, and reform. New York, NY: Cambridge University Press.

Torgler, B., \& Frey, B. S. (2012). Politicians: Be killed or survive. Public Choice, 156(1-2), 357-386.

van de Walle, N. (2001). African economies and the politics of permanent crisis, 1979-1999. New York, NY: Cambridge University Press.

van de Walle, N. (2012). The path from Neopatrimonialism: Democracy and Clientelism in Africa today. In D. C. Bach \& M. Gazibo (Eds.), Neopatrimonialism in Africa and beyond (pp. 111-123). Abingdon and New York, NY: Routledge.

Volkerink, B., \& de Haan, J. (2001). Fragmented government effects on fiscal policy: New evidence. Public Choice, 109(3-4), 221-242.

Wehner, J. (2010). Cabinet structure and fiscal policy outcomes. European Journal of Political Research, 49(5), 631-653.

Wehner, J., \& Mills, L. (2020). Cabinet size and governance in sub-Saharan Africa. In World Bank Policy Research Working Paper 9232. World Bank: Washington, DC.

Wehner, J., \& Mills, L. (2021). Replication data for: Cabinet size and governance in Sub-Saharan Africa. Harvard Dataverse. https://doi.org/10.7910/DVN/Q9NGJW

Woo, J. (2003). Economic, political, and institutional determinants of public deficits. Journal of Public Economics, 87(3-4), 387-426.

Woods, N. (2008). Whose aid? Whose influence? China, emerging donors and the silent revolution in development assistance. International Affairs, 84(6), 1205-1221.

How to cite this article: Wehner J, Mills L. Cabinet size and governance in SubSaharan Africa. Governance. 2021;1-19. https://doi.org/10.1111/gove.12575 


\section{APPENDIX A.}

Cabinet: The number of ministers with full cabinet rank, excluding other members of the executive without cabinet rank, notably junior or deputy ministers, and individuals with lower-level executive functions. Source: Arriola (2009) plus authors' updates from later editions of Europa Publications, Africa South of the Sahara.

Control of Corruption (CC): Captures perceptions of the extent to which public power is exercised for private gain, including both petty and grand forms of corruption, as well as "capture" of the state by elites and private interests. Rescaled so that most scores lie between about 0 and about 100, with higher scores corresponding to better outcomes. Source: September 2018 update of the Worldwide Governance Indicators, CCE.

Corruption Perceptions Index (CPI): Measure of perceived levels of public sector corruption according to experts and businesspeople. Ranges from 0 to 100, with higher scores corresponding to better outcomes. Source: Transparency International data compiled by Jeffry Jacob; we made a small number of corrections where missing values had accidentally been entered with a zero score.

Defense minister: Indicator of whether the defense minister is a military officer. $1=$ military officer, 0 = not a military officer. Source: Inter-American Development Bank, Database of Political Institutions 2017, DEFMIN.

Electoral democracy: Measure of the extent to which the ideal of electoral democracy is achieved. Ranges from 0 (not at all) to 1 (fully achieved). Source: July 2018 version of the VDem data set, v2x_polyarchy.

Executive Corruption Index (ECI), reversed: Measures how routinely members of the executive, or their agents grant favors in exchange for bribes, kickbacks, or other material inducements, and how often they steal, embezzle, or misappropriate public funds or other state resources for personal or family use. Rescaled to range from 0 (corrupt) to 100 (not corrupt). Source: July 2018 version of the V-Dem data set, v2x_execorr.

GDP per capita: Log of GDP per capita (constant 2010 US\$). Source: Word Bank, World Development Indicators, March 2019, NY.GDP.PCAP.KD.

Government Effectiveness (GE): Captures perceptions of the quality of public services, the quality of the civil service and the degree of its independence from political pressures, the quality of policy formulation and implementation, and the credibility of the government's commitment to such policies. Rescaled so that most scores lie between about 0 and about 100, with higher scores corresponding to better outcomes. Source: September 2018 update of the Worldwide Governance Indicators, GEE.

Government fractionalization: The probability that two deputies picked at random from among the government parties will be of different parties. Ranges from 0 to 1. Source: InterAmerican Development Bank, Database of Political Institutions 2017, GOVFRAC.

Ibrahim Index of African Governance, Human Development: Measures whether governments provide poverty mitigation and alleviation, educational advancement, health care and medical and sanitary services. Ranges from 0 to 100, with higher scores corresponding to better outcomes. Source: 2018 Ibrahim Index of African Governance.

Left: Party of the chief executive is communist, socialist, social democratic, or left-wing. $1=$ left, 0 = not left. Source: Inter-American Development Bank, Database of Political Institutions 2017, EXECRLC.

Military: Indicator of whether the chief executive is a military officer. $1=$ military officer, $0=$ not a military officer. Source: Inter-American Development Bank, Database of Political Institutions 2017, MILITARY. 
Polity: Revised Combined Polity Score ranging from -10 (strongly autocratic) to +10 (strongly democratic). Source: October 2018 version of the Polity IV data set, polity2.

Programmatic parties: Following Cruz and Keefer (2015), the share of the largest three government parties and the largest opposition party that are right, left, or center in their orientation. When the orientation of a political party is either not discernible in the sources employed or unrelated to economic policy, it is counted as non-programmatic. Ranges from 0 to 1. Source: Inter-American Development Bank, Database of Political Institutions 2017, GOV1RLC, GOV2RLC, GOV3RLC, OPP1RLC.

Regulatory Quality (RQ): Captures perceptions of the ability of the government to formulate and implement sound policies and regulations that permit and promote private sector development. Rescaled so that most scores lie between about 0 and about 100, with higher scores corresponding to better outcomes. Source: September 2018 update of the Worldwide Governance Indicators, RQE.

Rule of Law (RL): Captures perceptions of the extent to which agents have confidence in and abide by the rules of society, and in particular the quality of contract enforcement, property rights, the police, and the courts, as well as the likelihood of crime and violence. Rescaled so that most scores lie between about 0 and about 100, with higher scores corresponding to better outcomes. Source: September 2018 update of the Worldwide Governance Indicators, RLE.

Years in office: The number of years that the chief executive has been in office. Source: Inter-American Development Bank, Database of Political Institutions 2017, YRSOFFC.

Years to election: Years left in the current electoral term of the executive. Source: InterAmerican Development Bank, Database of Political Institutions 2017, YRCURNT.

TABLE A1 Summary statistics

\begin{tabular}{|c|c|c|c|c|c|}
\hline Variable & Obs & Mean & SD & Min & Max \\
\hline Cabinet & 1,797 & 22.809 & 7.632 & 5 & 53 \\
\hline Control of Corruption & 735 & 37.285 & 12.473 & 12.626 & 74.335 \\
\hline Corruption Perceptions Index & 594 & 30.017 & 11.173 & 8 & 65 \\
\hline Defense minister & 1,489 & 0.413 & 0.493 & 0 & 1 \\
\hline Electoral democracy & 1,797 & 0.334 & 0.208 & 0.072 & 0.851 \\
\hline Executive Corruption Index, reversed & 1,797 & 37.641 & 24.546 & 2.244 & 91.965 \\
\hline GDP per capita (logged) & 1,618 & 6.871 & 0.986 & 4.880 & 9.920 \\
\hline Government Effectiveness & 734 & 34.826 & 12.512 & 1.082 & 70.873 \\
\hline Government fractionalization & 1,351 & 0.123 & 0.223 & 0.000 & 0.876 \\
\hline Ibrahim Index, Human Development & 332 & 50.072 & 13.650 & 8.200 & 89.400 \\
\hline Left & 1,797 & 0.278 & 0.448 & 0 & 1 \\
\hline Military & 1,620 & 0.390 & 0.488 & 0 & 1 \\
\hline Polity & 1,729 & -1.282 & 6.032 & -9 & 10 \\
\hline Programmatic parties & 1,366 & 0.433 & 0.415 & 0.000 & 1.000 \\
\hline Regulatory Quality & 735 & 36.016 & 12.871 & -2.901 & 72.545 \\
\hline Rule of Law & 735 & 35.515 & 13.496 & -2.129 & 71.543 \\
\hline Years in office & 1,629 & 9.491 & 7.962 & 1 & 42 \\
\hline Years to election & 1,219 & 2.326 & 1.648 & 0 & 7 \\
\hline
\end{tabular}


TABLE A2 Correlations between governance measures

\begin{tabular}{|llllllll} 
& GE & RQ & RL & CC & CPI & ECI & IIAG \\
\hline Government Effectiveness & 1.000 & & & & & & \\
Regulatory Quality & 0.880 & 1.000 & & & & & \\
Rule of Law & 0.902 & 0.870 & 1.000 & & & & \\
Control of Corruption & 0.849 & 0.741 & 0.877 & 1.000 & & & \\
\hline Corruption Perceptions Index & 0.832 & 0.743 & 0.848 & 0.908 & 1.000 & & \\
\hline Executive Corruption Index, reversed & 0.629 & 0.542 & 0.681 & 0.801 & 0.696 & 1.000 & \\
\hline Ibrahim Index, Human Development & 0.869 & 0.760 & 0.839 & 0.781 & 0.810 & 0.576 & 1.000 \\
\hline
\end{tabular}

TABLE A3 Country codes used in Figure 3

\begin{tabular}{|c|c|}
\hline Country & Code \\
\hline Angola & AGO \\
\hline Benin & BEN \\
\hline Botswana & BWA \\
\hline Burkina Faso & BFA \\
\hline Burundi & BDI \\
\hline Cameroon & CMR \\
\hline Cabo Verde & $\mathrm{CPV}$ \\
\hline Central African Republic & $\mathrm{CAF}$ \\
\hline Chad & $\mathrm{TCD}$ \\
\hline Comoros & $\mathrm{COM}$ \\
\hline Congo, Rep. & $\mathrm{COG}$ \\
\hline Congo, Dem. Rep. & ZAR \\
\hline Côte d'Ivoire & CIV \\
\hline Equatorial Guinea & GNQ \\
\hline Eritrea & ERI \\
\hline Eswatini & SWZ \\
\hline Ethiopia & ETH \\
\hline Gabon & GAB \\
\hline Gambia, the & GMB \\
\hline Ghana & GHA \\
\hline Guinea & GIN \\
\hline Guinea-Bissau & GNB \\
\hline Kenya & KEN \\
\hline Lesotho & LSO \\
\hline Liberia & LBR \\
\hline Madagascar & MDG \\
\hline Malawi & MWI \\
\hline
\end{tabular}


TABLE A3 (Continued)

\begin{tabular}{|ll|}
\hline Country & Code \\
\hline Mali & MLI \\
\hline Mauritania & MRT \\
\hline Mauritius & MUS \\
\hline Mozambique & MOZ \\
\hline Namibia & NAM \\
\hline Niger & NER \\
\hline Nigeria & NGA \\
\hline Rwanda & RWA \\
\hline São Tomé and Príncipe & STP \\
\hline Senegal & SEN \\
\hline Seychelles & SYC \\
\hline Sierra Leone & SLE \\
\hline Somalia & SOM \\
\hline South Africa & ZAF \\
\hline Sudan & SDN \\
\hline Tanzania & TZA \\
\hline Togo & TGO \\
\hline Uganda & UGA \\
\hline Zambia & ZMB \\
\hline Zimbabwe & ZWE \\
\hline
\end{tabular}

Source: IMF International Financial Statistics. 